\title{
The Impact of Mergers and Acquisitions on Financial Performance of Banks in the Kingdom of Bahrain
} during 2004-15

\author{
Bushra A. Abdulwahab, Subhadra Ganguli* \\ Risk Management Department, Al Salam Bank, Bahrain \\ College of Business and Finance in Ahlia University, Kingdom of Bahrain \\ bushra.abdulwahab@gmail.com,"ssanguli@ahlia.edu.bh
}

\begin{abstract}
Following the 2007 global financial crisis, more than 15 M\&A transactions took place among financial institutions in the kingdom of Bahrain. This paper evaluates the impact of M\&As on the financial performance of four such deals between banks in Bahrain. Data was collected from financial statements of the banks and the Bankscope database during 2004-2015. 15 accounting ratios were applied to CAMEL Rating Model approach. Financial modelling with Excel has been applied to test for the significance of changes in the financial performance of the banks three years before and three years after mergers. No significant difference in the financial performance of the local banks between pre and post M\&As in the kingdom of Bahrain was observed. No significant difference in the financial performance of the acquirer bank or the target bank was observed except Bahraini Saudi Bank (target bank) which showed significant improvement in the financial performance after the merger with acquirer bank namely Al Salam Bank. No significant change in the overall CAMEL ratios was observed for all banks involved in the M\&As in Bahrain during 2004-15. The study provides an empirical analysis of the M\&As before and after the mergers which can serve as a basis for further evaluation of future strategy of the banking sector in the Kingdom of Bahrain.
\end{abstract}

Keywords: Kingdom of Bahrain, mergers and acquisitions, banks, financial performance, CBB

\section{Introduction and Literature Review}

The aim of this paper is to evaluate the effect of M\&As on the financial performance of merged local banks in Bahrain during 2004-2015 by applying the CAMEL rating model. As per the Central Bank of Bahrain (CBB), 17 M\&A transactions took place among financial institutions in the kingdom of Bahrain during 2004-15. The changing dynamics of global markets and progressively increasing competition has resulted in M\&As becoming an oft-used route for survival and sustainability. The CBB has supported M\&As in the banking sector, especially for those with lower capitalization, since this could potentially result in institutions becoming sustainable in the long run. Additionally, given the relatively small size of Bahrain's financial markets, financial consolidation seemed reasonable during post 2007 financial crisis.

The literature review is divided into two parts- first it considers the effects of M\&As on the target and the acquirer banks and secondly it studies the CAMEL model. The definition of a merger has been stated by Botis (2013) as the process of integration between two entities in which one or both will exist legally as one successor entity. Gitman et al. (2012) defined a merger as the combination of two or more firms with the larger of the firms keeping its own identity. On the other hand, Botis (2013) addressed acquisition as a transaction in which the acquiring entity gains ownership and control over the target entity. Gitman et al. (2012) mentioned that an acquiring company is an entity in a merger deal that attempts to acquire another entity, and the target company is the firm that is acquired. Kaur (2014) mentioned that some of the driving factors for M\&A include enhancement of market power, lower risk profile, expansion opportunities, replacement of inefficient management, diversification of products and markets and achievement of economies of scope and scale. These are considered as value maximization reasons for merger, while others could be hubris and for managerial purposes. Through M\&As, the banking sector aims to reach two main types of synergies: operating synergies (increasing revenue and/or reducing cost), and financial synergies (lowering the cost of capital through consolidation of one or more banks) (Ayadi et al., 2013). Beccalli \& Frantz (2013) stated that a bank's decision to initiate an M\&A process might be influenced by other external factors like economic environment, laws, and regulations. Central banks around the world have some influence on the integration and restructuring practices of financial institutions.

Many studies on M\&A practices in the banking sector have been conducted worldwide. According to Colombo and Turati (2014), banking M\&As started during the 1980s in the US followed by Western European 
countries in the 1990s. More than 1,500 mergers took place in the US banking sector during the period 199396 which was considered the largest such phenomenon during such period (Botis, 2013). Vitale and Laux (2012) analyzed the US banking sector post 2007 that included 105 M\&As. The results showed a decline in post-merger profitability. While assets grew marginally, there was little improvement in return and capital adequacy ratios. Knapp \& Gart (2014) examined the effect of M\&As on the credit risk of banks during 1991 2006. The findings showed that the NPL level and the loan charge-offs in the loan portfolio increased significantly during the post-merger period. Ayadi et al. (2013) studied 42 M\&A deals in Europe and compared them against 587 non-merging banks. Results showed that consolidated entities enjoyed better management quality in addition to greater economic efficiency and higher productivity gains. Colombo and Turati (2014) considered Italian banking sector during 1995 - 2006 and confirmed that a significant impact on the M\&A transaction process depends on the level of social development and regional economy. Based on Rasiah, Ming and Hamid (2014), Central Bank of Malaysia (called Bank Negara Malaysia) supported mergers of banks after the 1997 Asian financial crisis to reach economies of scale and provide higher levels of efficiency. Sufian et al. (2012) analyzed the effect of M\&As on the revenue efficiency of 34 commercial banks in Malaysia and showed no significant positive impact on the revenue efficiency of the banks during pre and post-merger periods.

Sinha, Kaushik \& Chaudhary (2010) showed that more than 50\% of the merged financial institutions $(17$ across India) improved their financial performance. Further, in the long run, consolidated entities reported higher cash flows, and greater cost savings. Kaur (2014) examined five major mergers during 2001-08 concluding significant gains to target companies while the acquirer received zero or negative gains. Examining the performance of the banking industry in Nigeria during pre and post M\&A (1981-2013), Amu \& Chigbu (2015) found significant improvement during post-M\&A period than before the M\&A with regards to the deposit of the private sector and increase in net assets of the banking sector. Moreover, Okpanachi (2011) provided comparative analysis of the impact of M\&As on financial efficiency. Michael (2013) stated that shareholders of banks in Nigeria received higher dividends in 2009 post M\&A than they received in 2003 prior to the M\&A; this concludes that the M\&A resulted in better value for the shareholders starting 2005 and during post M\&A. Abbas et al. (2015) confirmed that there was no significant improvement in the banks' financial performance during post M\&A period. Additionally, decreases in profitability, efficiency, liquidity and leverage ratios were reported. Lee et al. (2013) found that the cost efficiency decreased immediately after M\&As of Taiwanese banks; however, it took around three years to regain efficiency.

CAMEL Model: Financial performance refers to the bank's ability to generate sustainable profits (Rozzani \& Rahman, 2013). The CAMEL model is also used widely among banks in Bahrain to evaluate the quality of any lending or investment. This model was adopted in November 1979 by the Federal Financial Institutions Examination Council (FFIEC), USA for The Uniform Financial Institutions Rating System (UFIRS). The initial rating system evaluated the overall condition and performance of banks by assessing "Capital adequacy, Assets Quality, Management Administration, Earnings Quality and Liquidity Measurement". During January 1997, Federal Reserve introduced a revised rating system (the CAMELS model) which included a sixth component - "Sensitivity to Market Risk" (www.federalreserve.gov). Most related financial ratios of CAMEL stand as mandatory reporting requirements for banks in Bahrain in their financial disclosures to CBB. The various components of CAMEL include C for capital adequacy; A for Assets Quality; M for Management Quality; E for Earnings Quality; and L for Liquidity Position.

The first component of CAMEL is Capital Adequacy ratio. Khatik and Nag (2015) stated that capital adequacy reflects the stability and efficiency of the country's financial system. Boadi, Li \& Lartey (2016) mentioned that well capitalized banks have lesser need for external funding. As per the CBB, capital adequacy ratio is measured by a bank's total capital (Tier 1 "core capital" plus Tier 2 "supplementary capital") divided by its total risk-weighted assets. Banks in Bahrain are required to maintain a minimum capital adequacy ratio of 12.5\%. Boadi, Li and Lartey (2016), Abdul Rahman and Masngut (2014) and Erol et al. (2014) used the ratio of equity capital to total assets as reported in the bank's balance sheet to evaluate capital adequacy. Banking and Ratio Definitions (2011) defined the ratios of capital adequacy as: Tier 1 capital over risk weighted assets, total capital over risk weighted assets, tangible common equity over risk weighted assets, and shareholders' equity as a percentage of total assets. Disclosure reports contain, in addition to the capital structure and capital adequacy ratio, capital quality of the bank that can be tested through equity to liability 
ratio. The second component of CAMEL is Asset Quality. According to Lee et al. (2013), performance of the loans and financing instruments granted by the bank determines the quality of its assets and the degree of its financial strength. Asset quality, as stated by Knapp \& Gart (2014), can be measured by determining the proportion of bad loans and facilities in the loan book. The higher the ratio the more problematic the loans (assets) are. Non-performing loan ratio is a mandatory ratio that all banks in Bahrain need to report to CBB. Abdul Rahman \& Masngut (2014) used non-performing loans to total asset ratio to compute asset quality. Ferrouhi (2014) evaluated asset quality and Boadi, Li \& Lartey (2016) examined total loan to total assets in their study. Furthermore, Mishra \& Agarwal (2013) used total investment to total asset ratio.

The third covariate of CAMEL is Management Quality. Boadi, Li \& Lartey (2016) considered non-financial parameters such as staff quality, management control system, and organizational discipline to evaluate management quality. Financial parameters were evaluated by Mishra \& Agarwal (2013) through profits per employee and return on net worth ratios. Ferrouhi (2014) examined net income to total loans. Moreover, cost to income ratio was considered by Poghosyan \& Cihak (2011) and operating expense to total assets ratio was used by Boadi, Li \& Lartey (2016). Banking and Ratio Definitions (2011) evaluated efficiency through Operating Expense over Net Revenues ratio.

The fourth component of CAMEL is Earnings Quality. Earnings quality measures the ability to earn regularly and consistently in order to ensure sustainability and stability. Khatik \& Nag (2015), Boadi, Li \& Lartey (2016) and Ferrouhi (2014) evaluated earnings quality using Return on Average Assets Ratio (ROAA). Rasiah et al. (2014) defined ROAA as the profitability indicator. Besides ROAA, Return On Average Equity ratio (ROAE) is used as another parameter for earnings quality by Abdul Rahman \& Masngut (2014) and Poghosyan \& Cihak (2011). Rasiah et al. (2014) explained that ROAE indicates benefits that stockholders obtained from investing the required capital. Mishra \& Agarwal (2013) used interest income to total income ratio, and non-interest income to total income ratio for studying earnings quality of banks.

The fifth covariate of CAMEL is Liquidity which shows the ability of the bank to meet its financial obligations through liquid assets and short term funds. Previous studies by Khatik \& Nag (2015), Mishra \& Agarwal (2013), and Poghosyan \& Cihak (2011) evaluated the liquidity position by using liquid assets to total assets ratio. Ferrouhi (2014) used deposit to total assets ratio. Abdul Rahman \& Masngut (2014) measured net liquid assets over deposits and short term funding. Further, Boadi, Li \& Lartey (2016) examined total loans to total customer deposit ratio in order to evaluate liquidity of a bank.

\section{Methodology}

This research analyses the impact of a specific change (M\&A) on the financial performance of banks in Bahrain during 2004-15 and is considered a causal study. The research evaluates the performance of commercial banks through testing 15 CAMEL ratios for three years each during the pre and post M\&A periods using quantitative methods. The sample of mergers and acquisitions used for the study provides details of each of the M\&A deals studied during 2004 -15 and finally t-tests have been applied for testing null hypotheses. Table 1 provides details of each M\&A deal studied in the paper and CAMEL ratios used for the study have been highlighted in Table 2. Three years of financial data before the merger and three years after the merger were considered in this study. CAMEL ratios were calculated based on average of three year values prior to M\&A deals and average of three year values after the M\&A deals as mentioned in Table 1. Financial Modeling in Excel was carried out for all selected ratios in Table 2 using 3 years of pre M\&A data and 3 years post M\&A data for banks in Bahrain during 2004-2015. Three types of analyses have been used in this paper namely, paired sample t-test for all 15 CAMEL ratios to examine the significant difference between pre and post M\&A per deal; t-test (paired sample means) to evaluate the significant difference between the financial ratios in CAMEL during pre and post M\&A individually for each ratio reported for all deals and a ttest (paired sample means) to study the significant difference in the overall financial performance between pre and post M\&A periods.

Sample of the Study: 17 M\&A deals in the financial services sector in Bahrain during 2004-15 show two types of incorporations: local and branch incorporations. Twelve of these M\&As took the form of incorporations - branches and local integration - and included conventional banks (retail and wholesale); 
Islamic banks (wholesale) and investment banks. This paper focuses on local incorporations which involved 7 mergers (including commercial and investment banks). Four integration deals were selected representing commercial banks which are locally incorporated in Bahrain during 2004 -2015. Table 1 shows the details of the 4 merger deals completed during 2007-13 based on local incorporations. Deals 1, 23 and 4 are discussed in detail.

Table 1: M\&A Transactions of Interest

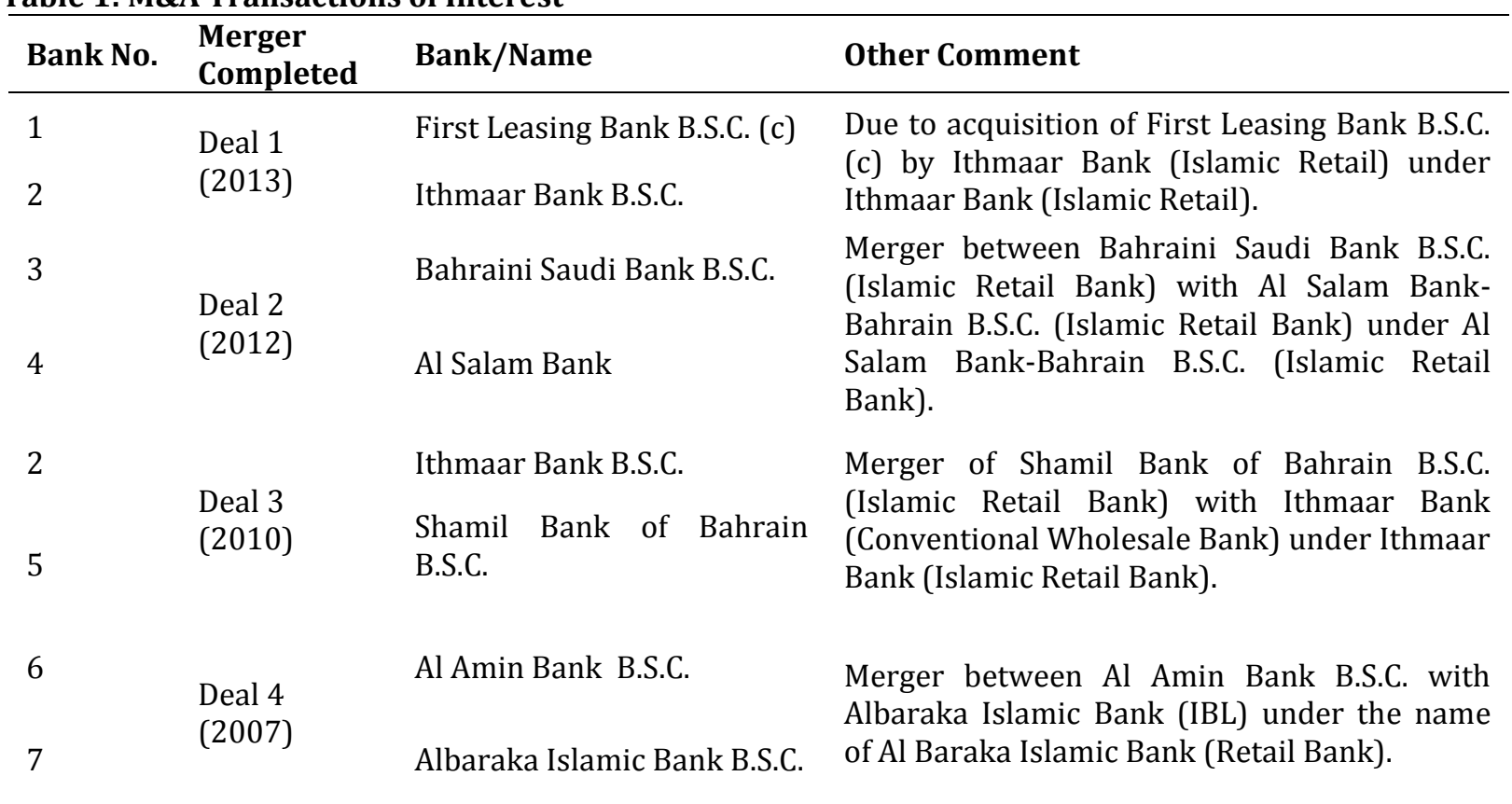

Deal (1): Ithmaar Bank with First Leasing Bank - 2013

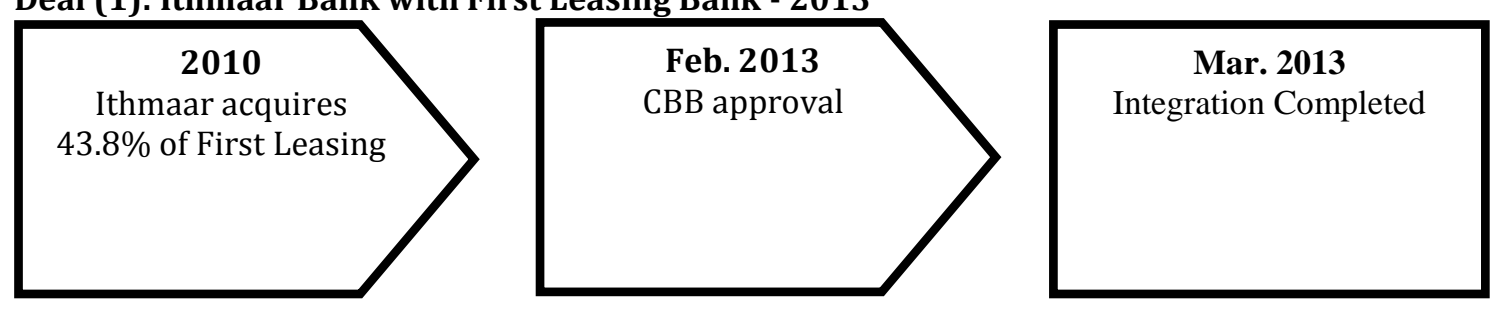

Merger of Ithmaar Bank with First Leasing Bank was considered as the latest fully completed integration that took place in Bahrain. First Leasing Bank was a subsidiary of Ithmaar Bank with 44\% ownership of total assets and was gradually fully integrated with Ithmaar. In February 2013, the CBB approved transferring the entire business operation from First Leasing Bank to Ithmaar Bank. The share swap was completed by March 2013.

Deal (2): Al Salam Bank-Bahrain with Bahraini Saudi Bank - 2012

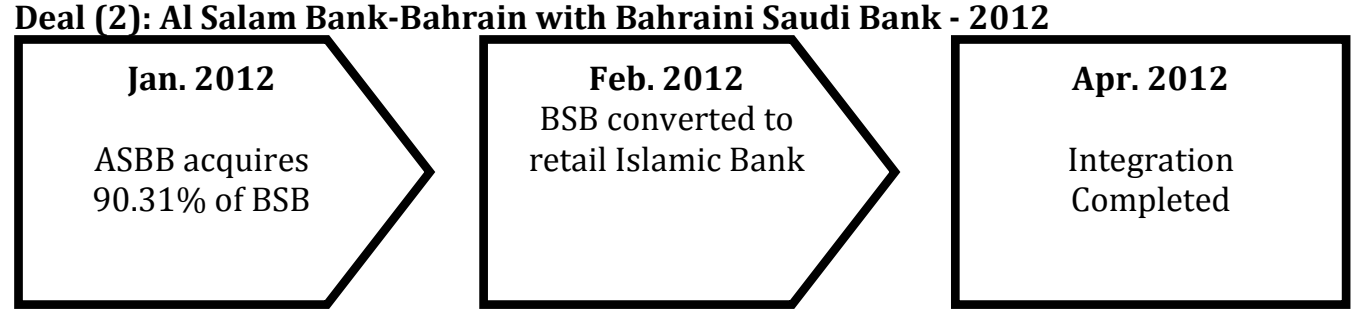

Bahraini Saudi Bank was established in December 1983. In 2009, Al Salam Bank acquired 90\% of Bahraini Saudi Bank and the acquisition of $100 \%$ stake was completed in August 2012. In February 2012, CBB 
approved the conversion of the license of BSB from retail conventional bank into retail Islamic bank and the merger was completed by 24 April 2012.

Deal (3): Ithmaar Bank with Shamil Bank of Bahrain - 2010

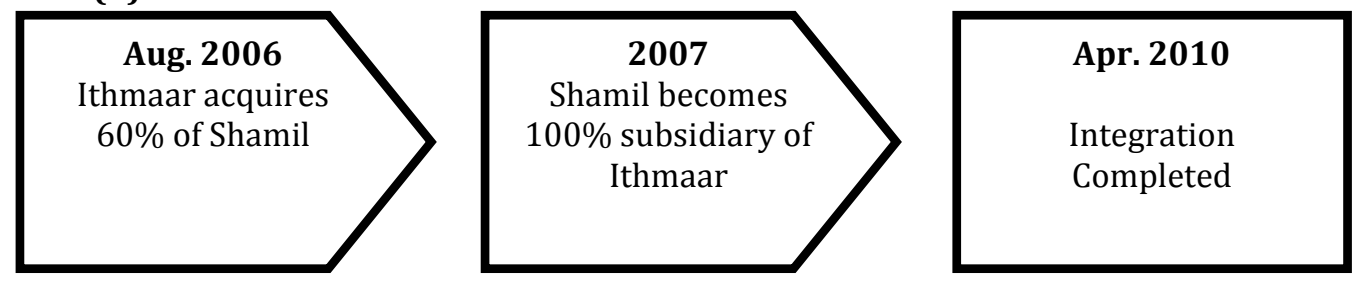

During August 2006 Ithmaar Bank purchased around 137 million shares (60\% ownership) of Shamil Bank Bahrain on the Bahrain Stock Exchange. Shamil Bank became a 100\% subsidiary of Ithmaar after the remaining $40 \%$ was acquired in 2007. The integration was officially concluded after the CBB approval in April 2010.

Deal (4): Albaraka Islamic Bank with Al Amin Bank - 2007

\begin{tabular}{|c|c|c|}
\hline $\mathbf{2 0 0 3}$ \\
\begin{tabular}{|c|} 
Al Amin owned \\
$100 \%$ by Al Baraka \\
Group
\end{tabular} \\
\end{tabular}

Table 2: Ratios Selected from the CAMEL Model

\begin{tabular}{ll}
\hline CAMEL Model Attribute & Included Ratio \\
\hline Capital Adequacy & Capital Adequacy Ratio \\
& Leverage ratio (E/L) \\
& NPL ratio \\
& Loans to Assets ratio \\
& Net Income to Total Loans \\
& Cost to Income ratio \\
Management Quality & Operating Expense to Total Assets \\
& Operating Expense to Net Interest Income \\
& Equity to Total Assets \\
& ROA \\
Earning Quality & ROE \\
& Interest Income to Total Income \\
& Liquidity ratio \\
& Deposit to Total Assets \\
& Loan to Deposit ratio \\
\hline
\end{tabular}

In 2003, the complete ownership of Al Amin Bank was transferred to Al Baraka Banking Group. Subsequently, Albaraka Islamic Bank (IBL) - another subsidiary of Al Baraka Banking Group - completed the acquisition of its sister bank in Bahrain namely, Al Amin Bank in 2007, under the name of Al Baraka Islamic Bank (Retail Bank). The integration of Albaraka Bank with Al Amin Bank is the oldest M\&A deal among the sample deals 
selected in the paper. Table 2 provides a list of ratios that have been considered for performance analysis of the banks before and after merger through detailed analysis of past literature.

Data: The financial results of the sample M\&A deals were collected from secondary sources such as Basel II / III, Pillar III, Public Disclosures as per CBB requirement for banks in Bahrain; annual reports and other published financial statements and Bank scope Database.

The research hypotheses are:

HOa: There is no significant difference in the CAMEL variables between pre and post M\&A.

H1a: There is significant difference in the CAMEL variables between pre and post M\&A.

HOb: There is no significant difference in the overall financial performance of the acquirer between pre and post M\&A periods.

H1b: There is a significant difference in the overall financial performance of the acquirer between pre and post M\&A periods.

HOc: There is no significant difference in the overall financial performance of the target between pre and post M\&A periods.

H1c: There is a significant difference in the overall financial performance of the target between pre and post M\&A periods.

HOd: There is no significant difference in the overall financial performance between pre and post M\&A periods for all banks in the Kingdom of Bahrain.

H1d: There is a significant difference in the overall financial performance between pre and post M\&A periods for all banks in the Kingdom of Bahrain.

\section{Results}

Camel Analysis for Each Deal-Financial Modelling with Excel

Deal (1): Ithmaar Bank with First Leasing Bank: Ithmaar Bank has gone through two M\&As during the period 2010 to 2012-first with Shamil Bank in 2010 and then with First Leasing Bank in 2012. First Leasing Bank was established in Bahrain since August 2004 as a closed Bahraini shareholding company. The 2010 integration with Shamil Bank could have had some influence on Ithmaar Bank and may have affected the results in the paper. Considering the ratios examined in this study using CAMEL Model, the paired sample ttest shows insignificant difference between the pre and post M\&A Deal (1) for both Ithmaar Bank (acquirer bank) and First Leasing Bank (target bank).

\begin{tabular}{lll}
\hline P-value & Acquirer Bank & Target Bank \\
\hline Ithmaar and First Leasing & 0.489449488 & 0.324747633 \\
\hline
\end{tabular}

Null hypotheses HOb and H0c are accepted for Deal (1). This implies that there was no significant difference between the CAMEL variables during pre and most merger periods for both the target and acquirer bank.

Deal (2): Al Salam Bank-Bahrain with Bahraini Saudi Bank: ASBB completed its acquisition of Bahraini Saudi Bank during Aug. 2012. On March 2014, ASBB acquired 100\% stake in BMI Bank B.S.C. However, the entire operation of integration (systems and branches) was targeted to be completed by 2017 under the name of ASBB. Hence, this deal was not included in this paper. Integration data pre- merger (2009 - 2011) was analyzed compared to three years of financial ratios post integration data (2012 - 2014). Overall paired sample t-test analysis for Deal (2) showed insignificant difference for ASBB (acquirer bank), while it reported significant difference for BSB (target bank). Test for Deal (2) resulted in significant difference towards positive outcomes for the target bank (BSB).

\begin{tabular}{lll}
\hline P-value & Acquirer Bank & Target Bank \\
\hline ASBB and BSB & 0.333236317 & 0.015260518 \\
\hline
\end{tabular}

Based on the t-test results, null hypothesis HOb is accepted for Deal (2). This implies that there is no significant difference in the financial performance of the acquirer bank during pre and post merger periods. 
However, null hypothesis H0c is rejected and alternative hypothesis H1c is accepted due to significant difference observed in the overall financial performance of the target bank (BSB) post M\&A. This means that there has been a significant difference in the overall financial performance of the target bank (BSB) in the post merger period compared to the financial performance during the pre-merger period.

Deal (3): Ithmaar Bank with Shamil Bank of Bahrain: Overall paired sample t-test analysis for Deal (3) showed insignificant difference between the pre and post M\&A for both Ithmaar Bank (acquirer bank) and Shamil Bank Bahrain (target bank).

\begin{tabular}{lll}
\hline P-value & Acquirer Bank & Target Bank \\
\hline Ithmaar and Al Shamil & 0.799428475 & 0.383241072 \\
\hline
\end{tabular}

Hence null hypotheses HOb and H0c are accepted for Deal (3). This implies that like Deal 1, there has been no significant improvement in the overall financial performance of both the target and the acquirer banks in the post merger period compared to the financial performance in the pre-merger period.

Deal (4): Albaraka Islamic Bank with Al Amin Bank: The ownership of Al Amin Bank was transferred to Al Baraka Banking Group in 2003; in 2007 the bank was acquired by its sister bank located in Bahrain named Albaraka Islamic Bank, under Al Baraka Banking Group. The financial analysis for the ratios was carried out for three years prior to integration from 2004 to 2006 and three years during post integration from 2007 to 2009. It was challenging to get accurate information from the secondary data sources, especially since $\mathrm{Al}$ Amin Bank no longer exists and the annual reports of Al Baraka Islamic Bank were available online from 2007. However, relevant ratios were used after adjustment or substitution with available ones. Capital Adequacy ratio for Al Amin Bank during 2004 to 2006 was not reported in the financial statements or in Bankscope database. Moreover, elements of Tier I and Tier II capital in addition to risk weighted assets were unavailable. Hence, a substitute ratio was used to evaluate the capital adequacy ratio for Al Amin Bank with available data. This ratio was shareholders' equity to total assets (Banking and Ratio Definitions, 2011). Nonperforming loans (financing assets) or impaired loans were not reported for 2004 in any of the secondary sources; hence, NPL ratio for this year was not available. Therefore, average NPL ratio of Al Amin Bank for only two years prior to the integration (2005 and 2006) was considered for deal (4) analysis. Al Amin's equity presented a significant portion of the balance sheet, reporting $92.5 \%$ of total assets pre M\&A; this matter affected capital adequacy ratio, equity to liabilities ratio, and equity to assets ratio. Overall paired sample t-test analysis for Deal (4) for Albaraka Bank and Al Amin Bank for all ratios used in the analysis show insignificant difference between pre and post M\&A periods for both banks.

\begin{tabular}{lll}
\hline P-value & Acquirer Bank & Target Bank \\
\hline Albaraka and Al Amin & 0.275210455 & 0.215864611 \\
\hline
\end{tabular}

Hence, null hypotheses HOb and H0c are accepted for Deal (4). This implies that there has been no significant difference in the financial performance of the target and the acquirer banks in the post merger period compared to the financial performance in the pre-merger period.

T-test: Paired Two Sample T- test for Means: T-test has been conducted using average of pre and post M\&A performance ratios (average three years) in order to evaluate the difference at $5 \%$ significance level between pre and post M\&A for each ratio for all sample banks. Table 3 showed results of the mean and $p$-value for each ratio of the CAMEL model parameters. There were insignificant differences between pre and post M\&A deals at 5\% significance level for all ratios examined in this study. Hence, null hypotheses could not be rejected for the ratios. This test implies that for all banks, there has been no significant difference between the CAMEL ratios in the pre-merger period and the post merger periods. This is similar to the results of evaluation of the mergers and acquisitions of banks in countries such as Pakistan by Abbas et al. (2015), Sufian et al. (2012) in Malaysia, Lee et al. (2013) in Taiwan and Vitale and Laux (2012) in the USA where no significant improvement in the financial performance of firms have been observed after the merger. However, the results of studies in Europe by Ayadi et al. (2013) show massive productivity gains by banks in the post 
merger period. These results are also contradictory to those of Sinha et al. (2010) where around 50\% of the merged banks improved their financial performance after the mergers.

Table 3: Mean of averages and p-values for each ratio for all banks

\begin{tabular}{llll}
\hline Ratios & Pre M\&A & Post M\&A & P-value \\
\hline Capital Adequacy Ratio & $\mathbf{0 . 3 9 4}$ & 0.174 & 0.077296567 \\
Leverage ratio (E/L) & $\mathbf{1 1 . 7 0 2}$ & 0.178 & 0.204825754 \\
NPL ratio & $\mathbf{0 . 2 0 6}$ & 0.126 & 0.222933187 \\
Loans to Assets ratio & $\mathbf{0 . 4 8 5}$ & 0.464 & 0.788281246 \\
Net Income to Total Loans & $\mathbf{0 . 0 0 1}$ & -0.007 & 0.884090235 \\
Cost to Income ratio & $\mathbf{0 . 6 9 1}$ & 0.816 & 0.242173789 \\
Operating Expense to Total Assets & $\mathbf{0 . 0 2 7}$ & 0.022 & 0.158261966 \\
Operating Expense to Net Interest Income & $\mathbf{1 . 8 8 4}$ & 1.268 & 0.283466974 \\
Equity to Total Assets & $\mathbf{0 . 3 6 7}$ & 0.149 & 0.107520284 \\
ROA & $\mathbf{0 . 0 0 6}$ & -0.003 & 0.67608475 \\
ROE & $\mathbf{0 . 0 0 0}$ & -0.033 & 0.326569447 \\
Interest Income to Total Income & $\mathbf{0 . 7 4 4}$ & 0.797 & 0.424008521 \\
Liquidity ratio & $\mathbf{0 . 2 4 6}$ & 0.203 & 0.450148517 \\
Deposit to Total Assets & $\mathbf{0 . 5 1 2}$ & 0.812 & 0.05357872 \\
Loan to Deposit ratio & $\mathbf{2 . 0 2 5}$ & 0.561 & 0.271126777 \\
\hline
\end{tabular}

T-Test: Paired Two Sample T-test for Overall Performance: The overall significant difference between pre and post M\&A performance of the banks is tested using a paired sample t-test in which the means of the averages was used for all ratios collectively.

Table 4: Paired Two Sample T-Test for Mean

\begin{tabular}{lll}
\hline & Average Pre & Average Post \\
\hline Mean & 1.286039626 & 0.368451457 \\
Variance & 8.693388174 & 0.157557265 \\
Observations & 15 & 15 \\
Pearson Correlation & 0.030677676 & \\
Hypothesized Mean Difference & 0 & \\
Df & 14 & \\
t Stat & 1.199409498 & \\
P(T<=t) one-tail & 0.125137461 & \\
t Critical one-tail & 1.761310115 & \\
P(T<=t) two-tail & 0.250274922 & \\
t Critical two-tail & 2.144786681 & \\
\hline
\end{tabular}

Table 4 results confirmed insignificant difference between pre and post M\&A. Hence, post completion of M\&A deals no significant difference in banks' performance in Bahrain was observed. Null hypotheses H0d could not be rejected. This implies that there has been no significant difference in the overall financial performance of the banks in the sample between pre and post merger periods in the kingdom of Bahrain. This is similar to the results of Abbas et al. (2015) in the context of the financial performance of the banks in Pakistan where no significant difference was observed in their financial performance between the pre and post merger periods. Table 5 summarizes hypothesis testing of the study. 
Table 5: Summary of Hypotheses Testing

\begin{tabular}{|c|c|c|c|}
\hline \multicolumn{2}{|c|}{ Hypothesis } & \multirow{2}{*}{$\begin{array}{l}\text { Deal No. } \\
\text { All Deals }\end{array}$} & \multirow{2}{*}{$\begin{array}{l}\text { Decision } \\
\text { Accepted }\end{array}$} \\
\hline $\mathrm{HOa}$ & $\begin{array}{l}\text { No significant difference in the CAMEL Model elements } \\
\text { between pre and post M\&A. }\end{array}$ & & \\
\hline $\mathrm{H} 1 \mathrm{a}$ & $\begin{array}{l}\text { Significant difference in the CAMEL Model elements between } \\
\text { pre and post M\&A. }\end{array}$ & All Deals & Rejected \\
\hline $\mathrm{HOb}$ & $\begin{array}{l}\text { No significant difference in the overall financial performance } \\
\text { of the acquirer bank post M\&A. }\end{array}$ & All Deals & Accepted \\
\hline $\mathrm{H} 1 \mathrm{~b}$ & $\begin{array}{l}\text { Significant difference in the overall financial performance of } \\
\text { the acquirer bank post M\&A. }\end{array}$ & All Deals & Rejected \\
\hline $\mathrm{HOc}$ & $\begin{array}{l}\text { No significant difference in the overall financial performance } \\
\text { of the target bank post M\&A. }\end{array}$ & $\begin{array}{l}\text { Deal (1) } \\
\text { Deal (2) } \\
\text { Deal (3) } \\
\text { Deal (4) }\end{array}$ & $\begin{array}{l}\text { Accepted } \\
\text { Rejected } \\
\text { Accepted } \\
\text { Accepted }\end{array}$ \\
\hline $\mathrm{H} 1 \mathrm{c}$ & $\begin{array}{l}\text { Significant difference in the overall financial performance of } \\
\text { the target bank post M\&A. }\end{array}$ & $\begin{array}{l}\text { Deal (1) } \\
\text { Deal (2) } \\
\text { Deal (3) } \\
\text { Deal (4) }\end{array}$ & $\begin{array}{l}\text { Rejected } \\
\text { Accepted } \\
\text { Rejected } \\
\text { Rejected }\end{array}$ \\
\hline HOd & $\begin{array}{l}\text { No significant difference in the overall financial performance } \\
\text { between pre and post M\&A of all banks in the Kingdom of } \\
\text { Bahrain. }\end{array}$ & All Deals & Accepted \\
\hline H1d & $\begin{array}{l}\text { Significant difference in the overall financial performance } \\
\text { between pre and post M\&A of all banks in the Kingdom of } \\
\text { Bahrain. }\end{array}$ & All Deals & Rejected \\
\hline
\end{tabular}

Based on Table 5 it can be concluded that the t-test for the difference between pre and post M\&A is insignificant and so the null hypotheses for all M\&A deals were accepted except the null hypotheses of H0c for deal 2. This implied that a significant difference was observed in the overall financial performance only for Bahraini Saudi Bank (BSB) between pre and post-merger periods.

Findings: The main objective of the paper was to investigate whether M\&As between the local banks in Bahrain had any positive impact on the financial performance of the banks before and after mergers which took place during 2004-15. Paired sample t-test for all ratios per deal for acquirer and target bank provided insignificant results for all deals. However, t-test showed significant difference in the financial performance of the target bank in deal (2) only where BSB results have shown positive impact of M\&A in the post merger period compared to the pre-merger period. The t-test (paired two sample for means) for the financial ratios during pre and post M\&A periods individually for each ratio reported for the four deals together showed insignificant difference in all ratios between the pre and post merger period values. This implied that there have been no significant difference in the financial performance of the target and acquirer banks due to the M\&A deals in Bahrain during 2004-15. Finally, paired two sample t-test for means which is t-test for the overall financial performance between pre and post M\&A periods resulted in insignificant difference between pre and post M\&A values for the local banks engaged in M\&A deals in Bahrain. This means that the financial performance of the banks did not improve after the M\&A. These results are similar to studies in other geographical areas, namely Pakistan, USA, Malaysia, and Taiwan (Abbas et al., 2015; Vitale \& Laux, 2012; Sufian et al., 2012; Lee et al., 2013).

\section{Conclusion and Recommendations}

The study has been conducted to explore the efficacy of M\&A deals in the banking sector in Bahrain during 2004-15. Four deals namely, between Ithmaar Bank with First Leasing Bank (Deal 1), Al Salam Bank-Bahrain with Bahraini Saudi Bank (Deal 2), Ithmaar Bank with Shamil Bank of Bahrain (Deal 3) and finally Albaraka Islamic Bank with Al Amin Bank (Deal 4) were analyzed and tested in this study. The objective of this study was to determine the impact of M\&As on the financial performance of the banks during a period of three years before each merger and a period of three years after each merger. The data used in this study was secondary in nature. The study was conducted to compare selected financial ratios for three years during pre 
and three years during post M\&A periods in which CAMEL rating approach with financial modelling in excel was followed. Three different tests used in this study namely, paired sample t-test for all ratios to examine the significant difference for pre and post M\&A for each deal and for any significant difference in the financial performance of the target and the acquirer banks before and after M\&A involved in each deal; $t$-test (paired two sample test for means) between the financial ratios pre and post M\&A individually for each ratio reported for all deals; and t-test (paired two sample t-test for means) for the overall financial performance between pre and post M\&A have been reported. The results showed that there were no significant improvements in the financial performance of the target or the acquirer banks after the mergers except in deal 2 where a significant improvement in Bahraini Saudi Bank's financial performance was noticed after merger with Al Salam Bank. The rest of the deals had no significant impact on the overall financial performance of either the target or the acquirer bank in Bahrain involved in mergers and acquisitions during 2004-15. There was no significant difference in the CAMEL model variables before and after mergers for the banks involved in the deals. Finally the paired sample t-test for the overall performance of the banks in the pre and post merger periods showed that there was no significant difference in the overall financial performance of the banks in the sample at 5\% level of significance between the pre and post merger periods. Since most of the results showed insignificant impact of M\&As on the financial performance of the merged banks, this study calls for a better evaluation of the impact and risks involved in such M\&A deals to be assessed before a merger in the future.

The CBB has supported M\&As in Bahrain due to the potential financial consolidation of the institutions which, in turn, would help banks overcome difficulties posed by the limited size of the Bahraini market and tougher regulatory and competitive market environment during the post 2007 financial crisis. Review of past literature has shown that the effect of M\&As across the globe have also produced very diverse results and no uniform pattern of improvement has been observed in the global markets in terms of success or failure of mergers and acquisitions. More often than not, the effect of mergers and acquisitions has produced either little or no positive impact on the target and acquirer companies. Some exceptions to this have been evidenced in studies by Amu \& Chigbu (2015), Okpanachi (2011) and Michael (2013) in the case of Nigeria where some remarkable improvements in the performance of the banks during post merger period have been observed. This paper proves that M\&A deals in Bahrain during 2005-14 have not produced desirable outcomes, at least during the three years immediately after the mergers. Given such immediate insignificant results of the M\&As it is recommended to further assess the impact of M\&As over an extended post merger period and also to consider alternative strategies to diversify, strengthen and regulate the financial sector of Bahrain by the CBB. As consolidation of the financial sector is imminent, given the disproportionately large number of financial institutions in an island with 1.3 million populations, alternative measures of boosting financial sector should be sought and implemented. This seems very important in the face of the continuing oil price slowdown globally and the urgent need for the GCC states (including Bahrain) to diversify their economies further towards alternative avenues to generate a robust private sector and minimise dependence on the hydrocarbons sector.

\section{References}

Abbas, Q., Hunjra, A., Saeed, R. Ehsan U. \& Ijaz, M. (2015). Analysis of Pre and Post Merger and Acquisition Financial Performance of Banks in Pakistan. Information Management and Business Review , 6(4), 177-190.

Abdul Rahman, R. \& Masngut, M. (2014). The Use of "CAMELS" in Detecting Financial Distress of Islamic Banks in Malaysia. The Journal of Applied Business Research , 30(2), 445-452.

Annual Reports and Financial results Al Baraka Bank, Bahrain. (2016). Retrieved Septemmber 2016, from Al Baraka Bank, Bahrain : http://www.albaraka.com/default.asp?action=category\&id=31 and http://www.albaraka.com/default.asp?action=article\&id=56

Annual Reports and Annual Financial Statements, Al Salam Bank. (2016). Retrieved September 15th, 2016, from Al Salam Bank, Bahrain 2016, Annual Reports and Annual Financial Statements,: http://www.alsalambahrain.com/Downloads/p13_sectionid/4 http://www.alsalambahrain.com/Downloads/p13_sectionid/9

and

Amu, C. \& Chigbu, E. (2015). Relationship between Pre and Post Merger and Acquisition Banking Industry Performance in Nigeria. Independent Journal of Management and Production , 6(3), 850-865. 
Ayadi, R., Boussemart, J., Leleu, H. \& Saidane, D. H. (2013). Mergers and Acquisitions in European banking higher productivity or better synergy among business lines? Journal of Productivity Analysis, , 39(2), 165-175.

Beccalli, E. \& Frantz, P. (2013). The Determinants of Mergers and Acquisitions in Banking. Journal of Financial Services Research , 43(3), 265-291.

Banking and Ratio Definitions. (2011, February). Retrieved August 20, 2016, from www.Moody's.com: https://www.moodys.com/sites/products/ProductAttachments/Banking\%20Account\%20and\%20R atio\%20Definitions.pdf

Boadi, E., Li, Y. \& Lartey, V. (2016). Role of Bank Specific, Macroeconomic and Risk Determinants of Banks Profitability: Empirical Evidence from Ghana's Rural Banking Industry. International Journal of Economics and Financial Issues, 6(2), 813-823.

Botis, S. (2013). Mergers and Acquisitions in the International Banking. Economic Sciences, 6(1), 119-126.

Central Bank of Bahrain (CBB) 2012, The Financial Sector, . (2012). Retrieved August 15, 2016, from The Central Bank of Bahrain : http://www.cbb.gov.bh/page-p-banking.htm and http://www.cbb.gov.bh/page-p-overview1.htm

Central Bank of Bahrain (CBB) 2012, Fact Sheet. (2012). Retrieved August 15, 2016, from The Central Bank of Bahrain : http://www.cbb.gov.bh/page-p-financial_sector_fact_sheet.htm

Colombo, L. \& Turati, G. (2014). Why do Acquiring Banks in Mergers Concentrate in Well-Developed Area? Regional Development and Mergers and Acquisitions (M\&As). Banking. Regional Studies , 48(2), 363381.

Erol, C., Baklaci, H., Aydogan, B. \& Tunc, G. (2014). Performance comparison of Islamic (participation) banks and commercial banks in Turkish banking sector. EuroMed Journal of Business , 9(2), 114-128.

Federal Reserve System. (n.d.). Retrieved August 25, 2016, from Board of Governors of the Federal Reserve System 1996, Press Release: http://www.federalreserve.gov/BoardDocs/press/general/1996/19961224/default.htm

Ferrouhi, E. (2014). Moroccan Banks Analysis Using CAMEL Model. International Journal of Economics and Financial Issues , 4(3), 633-627.

Gitman, L. J., Zutter, C. J., ElAli, W. \& Al Roubaie A. (2012). Principles of Managerial Finance. (A. W. Edition, Ed.) Essex, England: Perason Education Limited.

Ithmaar Bank 2016, Annual Reports and Financials,. (n.d.). Retrieved September 2016, from Ithmaar Bank: https://www.ithmaarbank.com/ithmaar-investor-relations/annual_reports and https://www.ithmaarbank.com/ithmaar-investor-relations/financial_reports

Kaur, T. (2014). Impact of Bank Mergers on Performance: A study of mergers in Indian Banking Industry. International Journal of Applied Financial Management Perspectives, 3(3), 1172-1181.

Keat, G. \& Philip, K. (2009). Managerial Economics, Economic Tools for Today's Decision Makers (5th ed.). Upper Saddle River, N.J: Pearson Prentice Hall.

Khatik, S. \& Nag, A. (2015). Performance Measurement System in India Banking Sector in CAMEL Framework: A Comparative Study of Private and Foreign Banks in India. Delhi Business Review, 16(1), 75-85.

Knapp, M. \& Gart, A. (2014). Post-merger changes in bank credit risk: 1991-2006. Managerial Finance, 40(1), 51-71.

Lee, T., Liang, L. \& Huang, B. (2013). Do Mergers Improve the Efficiency of Banks in Taiwan? Evidence from Stochastic Frontier Approach. The Journal of Developing Areas, 47(1), 395-416.

Michael, N. (2013). Bank Mergers and Acquisition and Shareholders Wealth Maximization in Nigeria. Journal of Applied Finance and Banking, 3(3), 255-270.

Mishra, S. \& Agarwal, K. (2013). Measuring Performance of Banks Using Camels Model: A Comparative Study of CBI and IB. International Journal of Management Research and Review, 3(5), 2914-2922.

Okpanachi, J. (2011). Comparative analysis of the impact of mergers and acquisitions on financial efficiency of bank in Nigeria. Journal of Accounting and Taxation, 3(1), 1-7.

Pasiouras, F., Tanna, S. \& Gaganis, Ch. (2011). What Drives Acquisitions in the EU Banking Industry? The Role of Bank Regulation and Supervision Framework, Bank Specific and Market Specific Factors. Financial Markets, Institutions \& Instruments, 20(2), 29-77.

Poghosyan, T. \& Cihak, M. (2011). Determinants of Bank Distress in Europe: Evidence from a New Data Set. Journal of Financial Services Research, 40(3), 163-184.

Rasiah, D., Ming, T. \& Hamid, A. (2014). Mergers Improve Efficiency of Malaysian Commercial Banks. International Journal of Economics and Finance, 6(8), 289-300. 
Rozzani, N. \& Rahman, R.A. (2013). CAMELS and performance evaluation of banks in Malaysia:Conventional versus Islamic. Journal of Islamic Finance and Business Research, 2(1), 36-45.

Sinha, N., Kaushik, K. \& Chaudhary, T. (2010). Measuring Post Merger and Acquisition Performance: An Investigation of Select Financial Sector Organizations in India. International Journal of Economics and Finance, 2(4), 190-200.

Sufian, F., Muhamad, J., Bany-Ariffin, A., Yahya, M. H. \& Kamarudin, F. (2012). Assessing the Effect of Mergers and Acquisitions on Revenue Efficiency: Evidence from Malaysian Banking Sector. Vision: The Journal of Business Perspective, 16(1), 1-11.

Vitale, R. \& Laux, J. A. (2012). The Economic Efficacy of Banking Mergers: 2006-2008. Journal of Applied Business Research , 28(6), 1211-1215. 